\title{
Effect of Environmental acidic pH on Oxygen Consumption in Different stages of Fish, Cyprinus carpio $(L)$
}

\author{
U. Srineetha ${ }^{1}$, M. Venkata Reddy ${ }^{2}$ and M. Bhaskar ${ }^{1}$ \\ 1.Department of Zoology, Sri Venkateswara University Department of Zoology, Tirupat-(A.P), \\ 2.Sri Krishnadevaraya University, Department of Zoology, Ananthapuramu-515055(A.P),
}

\begin{abstract}
The data in table 1 and 2 showed changes in the total respiration and unit oxygen consumption of the developmental stages of fresh water fish during short-term exposure and acclimation to sub lethal acidic ( $p H$ 5.5) media. The oxygen consumption of fry significantly depleted in all the days of exposure to sub lethal acidic pH 5.5 starting from first day to fourteen days of exposure. The rate of total oxygen consumption depletion was higher in second day followed by fourth and sixth day with a gradual decreased trend was observed in the depletion up to fourteenth day of exposure. Similarly it is also observed significant decrease of total oxygen consumption and also rate of oxygen consumption of fingerling on exposure to sub lethal acidic $p H$ in all the days of exposure, i.e., first day to fourteenth day when compared to control. The unit oxygen consumption of fry and fingerling on exposure to sub lethal pH media exhibited significant depletion when compared to control. The rate of depletion was more in the initial days of exposure and it was reduced gradually in $12^{\text {th }}$ and $14^{\text {th }}$ days of exposure. Further, the animal excretion was highly depleted in acclimated fry to sub lethal acidic media when compared to control. Similarly, excretory pattern of the fingerling also showed significant reduction on acclimation to sub lethal acidic medium over control. The tissue ammonia levels were also significantly depleted in both fry and fingerlings on acclimation to sub lethal acidic medium when compared to control (table 3). But the rate of depletion was more in fingerlings than to fry stage. It is concluded that the acclimation processes to sub lethal acidic medium induced compensatory changes in nitrogenous end products metabolism of fry and fingerlings while providing positive survival capacity under acidic stress conditions.
\end{abstract}

Key words: Acidic $p^{H}$, Ammonia, Cyprinuscarpio(L), Oxygen consumption and Sub lethal

\section{Introduction}

The cultivation of fish has improved significantly in India during past few decades and fishes are exposed to a wide variety of environmental stress factors during culture. Environmental stress is of prime importance during the course of exposure of an animal to different acidic media. Acidic medium is known to be the highly influencing to the most organisms and therefore low $\mathrm{pH}$ of aquatic medium is an important aspect of environmental pollution.

The oxygen consumption in fish has been considered as an index for denoting the intensity of metabolism as metabolic activity of an organism is increased by its oxygen utilization[1]. Respiration is an essential physiological activity of all the living organisms by which they obtain energy for carrying out all metabolic activities of the body[2]. The rate of oxygen consumption, which is the basic physiological parameter, serves as an indicator of physiological stress[2] and changes in the oxygen consumption could be used to evaluate any change that would occur in the metabolism due to alterations in the environment. Such stresses like acidic medium have been studied by[3,4] , heavymetals by Venkata Reddy et al., [5], pulp mill effluents by Reeta Kumari et al., [6], hydrocarbons by Percy [7] and natural stresses like temperature and salinity by Rakesh, et al., [8]. The above studies unequivocally suggest that the sensitive indicator of stress like $\mathrm{O}_{2}$ consumption in fishes exposed to pollutants is considerably increased and decreased; but studies involving the $\mathrm{O}_{2}$ consumption in different stages of the whole animal with reference to sub lethal effect of acidic media is very few in fishes which are of great commercial and economical value. Hence, an attempt is made in the present investigation to study the influence of acidic media on certain aspects of $\mathrm{O}_{2}$ consumption in major carp, Cyprinus carpio following exposure to the sub lethal concentration of acidic medium at different exposure periods.

\section{Materials and Methods:}

Cyprinu scarpio is selected as an experimental animal for the present investigation. It feeds on bottom insects and other small invertebrates. It is a deep bodied individual with a few scales, rapidly grow and available abundantly in and around Tirupati. Because of the food value and economic importance, adaptability to laboratory conditions, the Cyprinus carpio is suitable for the present study.

\subsection{Procurement and Maintenance of Experimental Material.}

The experimental material consists of two stages of the fish, Cyprinus carpio 
* Fry stage ( after the fifth day of hatching),

- Fingerling stage (30 days after hatching)

They were collected as for the recommendation of the local Department of Fisheries, Government of Andhra Pradesh, India. The different stages were kept in large aquaria with continuously flowing dechlorinated water to acclimatize them to laboratory conditions $\left(27 \pm 2^{\circ} \mathrm{c}, \mathrm{pH} 7.0 \pm 0.2\right.$ and light period of $12 \mathrm{~h}$ per day) for five days, before they were used for experimentation.

\subsection{Preparation of different $\mathrm{pH}$ media}

The acidic media with different $\mathrm{pH}$ ranging between 3.0 to 7.0 with a variability of 0.5 were prepared

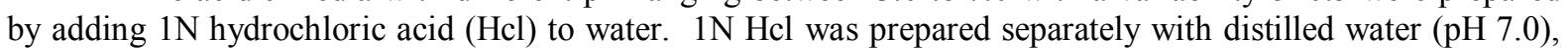
soft water, chlorides $(110 \mathrm{mg} /$ lit \pm 10$)$, carbonates $(16 \mathrm{mg} /$ lit \pm 2$)$, bicarbonates $(400 \mathrm{mg} / \mathrm{lit} \pm 50)$, hardness $(35$ $\mathrm{mg} / \mathrm{lit}$ as $\left.\mathrm{CaCo}_{3} \pm 4\right)$. The $1 \mathrm{~N} \mathrm{Hcl}$ was added for the purpose of obtaining different acidic media mentioned above and their $\mathrm{pH}$ were verified with $\mathrm{pH}$ meter (Elico, india). The chloride ions are least toxic and hence hydrochloric acid was used widely for the preparation of acid media. A number of investigators have used hydrochloric acid to prepare acidic media[9].

\subsection{Determination of Percentage Mortality of the Fish.}

The water media having different $\mathrm{pH}$ ranges between 3.0 to 7.0 with variability of $\pm 0.5 \mathrm{pH}$ were taken. For each $\mathrm{pH}$ medium in the above range 10 separate tanks were maintained with fingerling and fry stages each tank containing 25 individuals. The fish and its developmental stages were fed daily at 8 am with commercial fish pellets and the medium in the tanks was changed at $9 \mathrm{am}$. The $\mathrm{pH}$ of the media was maintained constantly by employing special dropping system during experimentation. The number of fish that died in each of the above media was recorded at regular intervals of time up to 96 hours. The percentage of mortality was calculated on the basis of individuals that died at each time interval. The media where the mortality of the fish was observed were taken as lethal media, and the others where was no mortality were taken as sub lethal media.

\subsection{Acclimation of Fish to Sub lethal Acidic medium.}

The sub lethal acidic medium $(\mathrm{pH} 5.5)$ was employed as an ambient medium for the acclimation of fish. The fish were fed daily at 8 am with commercial fish pellets and the medium in the tanks was changed at 9 $\mathrm{am}$. The fish were taken into the respiratory chamber containing the same $\mathrm{pH}$ medium at $2.00 \mathrm{pm}$ on alternate days and the oxygen consumption was determined with in a period of 1hour. After this the fish was transferred into their respective tanks.

\subsection{Estimation of oxygen consumption:}

The oxygen consumption of fish was determined by the static method described by Saroja [10]. The unit oxygen consumption was calculated by dividing the oxygen consumption by weight of the fish and represent as $\mathrm{mg} \mathrm{O} 2 / \mathrm{g} / \mathrm{h}$.

\subsection{Statistical treatment of data:}

All the values of $t^{\prime}$ ' below $5 \%$ levels are considered as not significant and the 5 percent level are considered as significant.

\section{Results and Discussion:}

The $\mathrm{pH}$ of water plays an important role in regulation of growth and development of aquatic animals. An attempt was made in the present study to find out the impact of acidic medium on fry and fingerling of Cyprinus carpio (L). The following parameters were carried out to observe the sub lethal effects of acidic medium in relation to unit oxygen consumption and excretory pattern in the media and tissues both in fry and fingerling. The present study was aimed to find out the relationship between environmental acidification on the growth and development of Cyprinus carpio(L).

The measurement of oxygen consumption has become a marker to understand the overall changes that takes place in the whole body on exposure to any stress condition. Several investigators[11,12,13] reported that the level of whole oxygen consumption was an index for metabolic modulations that takes place in the body on exposure to acidic stress. The total oxygen consumption was significantly decreased on first day of exposure to sub lethal acidic pH 5.5 media and exhibited a non -significant change over control on fourteenth day of exposure. This observation indicates that the fry and fingerling were capable of regulating their metabolic modulations and physiological functions through acclimation process to compensate the acidic stress imposed by the external media. This might be possible reason for the successful survival of fry and fingerling in acidifying water. The decreased oxygen consumption was observed in both fry and fingerling on exposure to sub lethal acidic media after one day. Decrease in total oxygen consumption might be due to hypoxic condition 
prevailed in external media. Another reason might be due to reduced gasses exchange through gill surface because of excessive formation of mucous. The other alternative could be the reduced oxygen carrying capacity of the blood due to altered blood $\mathrm{pH}$ on exposure to acidic media. Several investigators also reported earlier in supporting to the present study that decreased ability of fish to extract oxygen from low $\mathrm{pH}$ waters $[14,15]$

The reduced oxygen consumption of fry and fingerling on exposure to sub lethal acidic media confirms that prevalence of hypoxic condition in the surrounding media. Since the unit oxygen consumption also exhibited similar depletion trend suggests the possibility of existence of hypoxic conditions. The unit oxygen consumption of fry and fingerling also exhibited non significant change in $14^{\text {th }}$ day exposure. This observation support and form a basic evidence for the perfect type of acclimation by fry and fingerling. Since the total oxygen consumption in animals which forms a marker for the general metabolism, the stabilization of total oxygen consumption in fourteen days exposed fry and fingerling reflects the maintenance of normal oxygen consumption on par with the control fish. Hence, two weeks period of exposure of fry and fingerling to acidic media made successful in survival through acclimation process, failure of such a regulatory mechanism, might be responsible for the mortality of fry and fingerling at lethal $\mathrm{pH}$ media. In view of acclimation of fry and fingerling to acidic media provided better survival value changes at whole animal levels revel the better survival value. Hence, the studies have been extended to understand the other possible compensatory mechanisms, such as nitrogenous end products and excretory process, meanwhile to study and provide more information. So, the studies have been extended to observe the alterations in nitrogenous end products in both media and tissue levels.

The excretion of ammonia recorded significant decrease in both fry and fingerlings on exposure to sub lethal acidic medium. The decreased ammonia excretion might be due to inhibited ammonia production in the body. The decreased ammonia excretion suggests the possibility of reduced ammonia formation through the inhibited amino acid oxidative reactions in both fry and fingerlings of Cyprinus carpio (L) on exposure to sub lethal acidic media. Elevated amino acid levels were reported in fish on accumulation to acidic media.[15,16,4] . This supports that the reduced amino acid oxidation could be the possible reason for the inhibited ammonia levels in the present study. Other alternative for the decreased ammonia excretion could be utilization of ammonia towards maintenance of blood $\mathrm{pH}$ to counteract the acidic stress. Since the blood $\mathrm{pH}$ of tissue was decreased in fish on exposure to acidic media[17,18] the possibility of involvement of ammonia in buffering reactions leading to maintenance of blood $\mathrm{pH}$ could be the probable reason for the reduced ammonia excretion in fry and fingerlings on exposure to sub lethal acidic media.

The tissue ammonia levels also showed significant reduction in both fry and fingerlings on exposure to sub lethal acidic medium. The decreased ammonia levels might be due to inhibited ammonia production in tissue or its mobilization into other metabolic activity. The diversion of ammonia into the formation of other compounds such as urea and glutamine could be the possible reason for decreased ammonia levels in tissues in the present study. The conversion of animals from ammonotelic to ureotelic was reported earlier under various stress conditions[19-21]. Since glutamine participates in the neutralization activities during different stress conditions $[3,22,5]$ the ammonia might be mobilization for the synthesis of glutamine. So, the mobilization of tissue ammonia towards the formation of glutamine can be expected which might be another possible reason for reduced ammonia level in tissue of both fry and fingerlings on exposure to sub lethal acidic media.

\section{Conclusion:}

Finally it is concluded that the acclimation processes to sub lethal acidic medium induced compensatory changes in nitrogenous end products metabolism of fry and fingerlings while providing positive survival capacity under acidic stress conditions. So, the acidic media not only impact on the increased duration of experimentation but also developmental stages of fish.

\section{References:}

[1]. BijayBhushan Prasad, Mandip, and K.R Roy, Effect of copper sulphate and potassium dichromate on oxygen consumption of the air breathing fish, Channagachua, J.Ecotoxicol . Environ .Monit. 16(1),2003,71-76.

[2]. M Bhaskar, and S. Govindappa, Acclimation to sublethal acidic and alkaline media of Tilapia mossambica (peters); changes in glycogen metabolism of Red muscle, Bull. Environ. Contam.Toxicol., 37,1986,113.

[3]. A Sreenivasa Reddy, M. Venkata Reddy, and K. Radhakrishnaiah, Impact of copper on the oxidative metabolism of the fry of commom carp, Cyprinuscarpio (Linn) at different $\mathrm{P}^{\mathrm{H} .}$, Journal of Environmental Biology, 29(5),2008, 721-724.

[4]. U Srineetha, M. Venkata Reddy, and M. Bhaskar, Effect of environmental acidic $\mathrm{p}^{\mathrm{H}}$ on protein metabolism of freshwater fish, Cyprinuscarpio(L).,Eco. Envi.and Con,. 20(1),2014b, 125-129.

[5]. M.Venkata Reddy, M. Haranadha Reddy, and K. Radhakrishnaiah, Changes in protein metabolism and histology of the hepatopancreas of the snail Pilaglobosa (Swainson) on the exposure to the lethal and sublethal concentrations of nickel, Indian J. Fish., 58(3),2011,103-107.

[6]. RN ReetaKumari, Pathak, and P. Rani, Ecological status of river Daha in north Bihar and its effects on fish diversity, Nature Environment and Pollution Technology,10(2), 2011, 293-295.

[7]. JA Percy, Fate and effect of petroleum hydrocarbons in marine organisms and ecosystem, J. Exp. Bio., pp.1977, 192-200. 
[8]. K Rakesh, K. Pandey, D. Shobha, and V. Krishna Das, Temperature dependent mortality and behavioral changes in a freshwater mussel, Lamellidensmarginalis to dimethoate exposure, J. Envi. Biol., 34, 2013,165-170.

[9]. J.R.F Jones, .Acids and alkaline $\mathrm{pH}$ tolerance limits. In fish and liver pollution;( Butter worthco.Ltd., Canada. 107-117, 1968).

[10]. K. Saroja, Studies on the oxygen consumption in tropicalpoikilotherms II. Oxygen consumption in relation to body size and temperature in earthworm MeascolexMauriti when kept submerged under water. Proc.49b Ind. Acad. Sci., 1959,183-193.

[11]. JR Hazel, and C.L. Prosser, Molecular mechanisms of temperature compensation in Poikilotherms, Physiol. Rev. 54, 1974, 620677.

[12]. VK. Murthy, E.Madhuri, V. Sailaja, M. Bhaskar, and S. Govindappa, Studies on the red muscle lipid metabolism of the fish, Sarotherodonmossambicus (Trewavs)on exposure to sub lethal acidic media, J.Aqua.Biol., 14(1\&2), 1999, 83-85.

[13]. U Srineetha, M. Venkata Reddy, and M. Bhaskar, Effect of environmental acidic $\mathrm{p}^{\mathrm{H}}$ on oxygen consumption of fish, Cyprinuscarpio(L).,Nat. Env. \& Poll. Tech., 12(4), 2013a, 721-724.

[14]. R.K. Packer, and W.A. Dunson, Anoxia and Sodium loss associated with death of brook trout, Comp. Biochem.Physiol., 41A, 1972, 17-26.

[15]. V Sailaja, and M. Bhaskar, The effect of environmental factors on the physiology of prawn, J.Environ.Biol, 5(3), 2001, $122-126$.

[16]. P.Sobha Rani, E. Madhuri, V. Sailaja, M. Bhaskar, and S. Govindappa, Changes in the excretory products of fish red muscles on acclimation to low $\mathrm{P}^{\mathrm{H}}$, J.Aqua.Biol.,14(1\&2), 1999, 87-89.

[17]. CM Neville, Ventilatory response of rainbow trout (Salmogairdneri) to increased hydrogen ion concentration in blood and water, Comp. Biochem. Physiol,,63A, 1979, 373-376.

[18]. F.A.O, FAO yearbook. Fishery and Aquaculture Statistics. Rome, ( FAO, 78, 2010).

[19]. R. Sasikala, Changes in excretory pattern and detoxification mechanisms in fish, SarotherodonMossambicusunder ambient ammonia stress.M.Phil.,Dissertation, S.V. University.Tirupati, India, 1981.

[20]. KL. Sachidanandamurthy, and H.N. Yajurvedi, A study on physicochemical parameters of an aquaculture body in Mysore city, Karnataka, India, J. Environ. Biol., 27, 2006, 615-618.

[21]. RV. Kumar, K.S. Ramesh, PrakashPatil, B.T. Naveen Kumar, and K. Joseph Manissery, Dietary protein requirement of stunted fingerlings of rohu, Labeorohita (Hamilton) during gow-out stage, Indian J.Fish., 58 (4),2011, 49-53.

[22]. S. Ayyappan, Handbook of Fisheries and Aquaculture, (ICAR, New Delhi, 2010).

Table -1 Changes in total oxygen consumption ( $\mathrm{mg} \mathrm{O}_{2} / \mathrm{h} /$ fry or fingerling) of fry and fingerling during different days of exposure to sub lethal acidic media in comparison to control.

\begin{tabular}{|c|c|c|c|c|c|}
\hline \multirow[t]{2}{*}{ S.No } & \multirow[t]{2}{*}{ Time in (days ) } & \multicolumn{2}{|c|}{ Fry } & \multicolumn{2}{|c|}{ Fingerling } \\
\hline & & $\begin{array}{l}\text { Control } \\
(\mathrm{pH} 7.0)\end{array}$ & $\begin{array}{l}\text { Sublethal } \\
\text { (pH 5.5) }\end{array}$ & $\begin{array}{l}\text { Control } \\
(\mathrm{pH} 7.0)\end{array}$ & $\begin{array}{c}\text { Sublethal } \\
\text { (pH 5.5) }\end{array}$ \\
\hline 1 & 1 & $\begin{array}{l}0.0874 \\
\pm 0.005\end{array}$ & $\begin{array}{c}0.066 \\
\pm 0.0014 \\
-24.49 \\
\mathrm{P}<0.001\end{array}$ & $\begin{array}{c}0.202 \\
\pm 0.0021\end{array}$ & $\begin{array}{c}0.128 \\
\pm 0.002 \\
-36.51 \\
\mathrm{P}<0.001\end{array}$ \\
\hline 2 & 2 & $\begin{array}{l}0.0814 \\
\pm 0.004\end{array}$ & $\begin{array}{c}0.059 \\
\pm 0.0002 \\
-31.94 \\
\mathrm{P}<0.001\end{array}$ & $\begin{array}{c}0.201 \\
\pm 0.0024\end{array}$ & $\begin{array}{c}0.121 \\
\pm 0.002 \\
-39.59 \\
\mathrm{P}<0.001\end{array}$ \\
\hline 3 & 4 & $\begin{array}{l}0.0876 \\
\pm 0.007\end{array}$ & $\begin{array}{c}0.064 \\
\pm 0.007 \\
-26.02 \\
\mathrm{P}<0.001\end{array}$ & $\begin{array}{c}0.203 \\
\pm 0.0032\end{array}$ & $\begin{array}{c}0.132 \\
\pm 0.001 \\
-34.70 \\
\mathrm{P}<0.001\end{array}$ \\
\hline 4 & 6 & $\begin{array}{l}0.0870 \\
\pm 0.006\end{array}$ & $\begin{array}{c}0.066 \\
\pm 0.005 \\
-23.95 \\
\mathrm{P}<0.001\end{array}$ & $\begin{array}{c}0.201 \\
\pm 0.0021\end{array}$ & $\begin{array}{c}0.137 \\
\pm 0.0015 \\
-31.85 \\
\mathrm{P}<0.001\end{array}$ \\
\hline 5 & 8 & $\begin{array}{l}0.0872 \\
\pm 0.007\end{array}$ & $\begin{array}{c}0.0663 \\
\pm 0.002 \\
-23.95 \\
\mathrm{P}<0.001 \\
\end{array}$ & $\begin{array}{c}0.205 \\
\pm 0.0010\end{array}$ & $\begin{array}{c}0.160 \\
\pm 0.0010 \\
-21.82 \\
\mathrm{P}<0.001 \\
\end{array}$ \\
\hline 6 & 10 & $\begin{array}{l}0.0873 \\
\pm 0.007\end{array}$ & $\begin{array}{c}0.070 \\
\pm 0.005 \\
-18.90 \\
\mathrm{P}<0.001\end{array}$ & $\begin{array}{c}0.206 \\
\pm 0.0030\end{array}$ & $\begin{array}{c}0.164 \\
\pm 0.012 \\
-20.31 \\
\mathrm{P}<0.001\end{array}$ \\
\hline 7 & 12 & $\begin{array}{l}0.0878 \\
\pm 0.005\end{array}$ & $\begin{array}{c}0.077 \\
\pm 0.0009 \\
-11.62 \\
\mathrm{P}<0.001\end{array}$ & $\begin{array}{c}0.201 \\
\pm 0.0021\end{array}$ & $\begin{array}{c}0.169 \\
\pm 0.0060 \\
-16.12 \\
\mathrm{P}<0.001\end{array}$ \\
\hline 8 & 14 & $\begin{array}{l}0.0867 \\
\pm 0.004\end{array}$ & $\begin{array}{c}0.083 \\
\pm 0.002 \\
-3.22 \\
\text { NS }\end{array}$ & $\begin{array}{c}0.203 \\
\pm 0.0030\end{array}$ & $\begin{array}{c}0.196 \\
\pm 0.0062 \\
-2.24 \\
\mathrm{NS}\end{array}$ \\
\hline
\end{tabular}

Mean \pm SD, + and - indicates percent increase and decrease , ' $p$ ' denotes statistical significance and NS. Non-significant. 
Effect of Environmental acidic pH on Oxygen Consumption in Different stages of Fish, Cyprinus,

Table-2 Changes in unit oxygen consumption ( $\mathrm{mg} \mathrm{O}_{2} / \mathrm{h} / \mathrm{gm}$ wet wt) of fry and fingerling during different days of exposure to sub lethal acidic media in comparison to control.

\begin{tabular}{|c|c|c|c|c|c|}
\hline \multirow{2}{*}{ S.No } & \multirow{2}{*}{ Time in (days) } & \multicolumn{2}{|c|}{ Fry } & \multicolumn{2}{|c|}{ Fingerling } \\
\hline & & $\begin{array}{l}\text { Control } \\
(\mathrm{pH} 7.0)\end{array}$ & $\begin{array}{c}\text { Sublethal } \\
\text { (pH 5.5) }\end{array}$ & $\begin{array}{r}\text { Control } \\
(\mathrm{pH} 7.0)\end{array}$ & $\begin{array}{l}\text { Sublethal } \\
(\mathrm{pH} 5.5)\end{array}$ \\
\hline 1 & 1 & $\begin{array}{c}2.058 \\
\pm 0.010\end{array}$ & $\begin{array}{c}1.544 \\
\pm 0.024 \\
-24.97 \\
\mathrm{P}<0.001\end{array}$ & $\begin{array}{c}0.538 \\
\pm 0.0067\end{array}$ & $\begin{array}{c}0.343 \\
\pm 0.0018 \\
-36.24 \\
\mathrm{P}<0.001\end{array}$ \\
\hline 2 & 2 & $\begin{array}{c}2.044 \\
\pm 0.024\end{array}$ & $\begin{array}{c}1.411 \\
\pm 0.081 \\
-30.96 \\
\mathrm{P}<0.001\end{array}$ & $\begin{array}{c}0.544 \\
\pm 0.0074\end{array}$ & $\begin{array}{c}0.324 \\
\pm 0.0043 \\
-40.62 \\
\mathbf{P}<0.001\end{array}$ \\
\hline 3 & 4 & $\begin{array}{c}2.034 \\
\pm 0.030\end{array}$ & $\begin{array}{c}1.54 \\
\pm 0.050 \\
-24.55 \\
\mathrm{P}<0.001\end{array}$ & $\begin{array}{c}0.542 \\
\pm 0.0039\end{array}$ & $\begin{array}{c}0.336 \\
\pm 0.0024 \\
-38.19 \\
\mathrm{P}<0.001\end{array}$ \\
\hline 4 & 6 & $\begin{array}{c}2.074 \\
\pm 0.050\end{array}$ & $\begin{array}{c}1.551 \\
\pm 0.080 \\
-25.26 \\
\mathrm{P}<0.001\end{array}$ & $\begin{array}{c}0.536 \\
\pm 0.0017\end{array}$ & $\begin{array}{c}0.362 \\
\pm 0.021 \\
-32.46 \\
\mathrm{P}<0.001\end{array}$ \\
\hline 5 & 8 & $\begin{array}{c}2.041 \\
\pm 0.044\end{array}$ & $\begin{array}{c}1.573 \\
\pm 0.022 \\
-22.76 \\
\mathrm{P}<0.001 \\
\end{array}$ & $\begin{array}{c}0.545 \\
\pm 0.0027\end{array}$ & $\begin{array}{c}0.429 \\
\pm 0.0094 \\
-21.26 \\
\mathrm{P}<0.001 \\
\end{array}$ \\
\hline 6 & 10 & $\begin{array}{c}2.042 \\
\pm 0.011\end{array}$ & $\begin{array}{c}1.606 \\
\pm 0.024 \\
-21.40 \\
\mathrm{P}<0.001 \\
\end{array}$ & $\begin{array}{c}0.546 \\
\pm 0.0055\end{array}$ & $\begin{array}{c}0.440 \\
\pm 0.0046 \\
-19.31 \\
\mathrm{P}<0.001 \\
\end{array}$ \\
\hline 7 & 12 & $\begin{array}{c}2.053 \\
\pm 0.021\end{array}$ & $\begin{array}{c}1.855 \\
\pm 0.0110 \\
-9.64 \\
\mathrm{P}<0.001\end{array}$ & $\begin{array}{c}0.544 \\
\pm 0.0048\end{array}$ & $\begin{array}{c}0.452 \\
\pm 0.024 \\
-16.85 \\
\mathrm{P}<0.001 \\
\end{array}$ \\
\hline 8 & 14 & $\begin{array}{c}2.064 \\
\pm 0.020\end{array}$ & $\begin{array}{c}1.983 \\
\pm 0.012 \\
-3.92 \\
\text { NS }\end{array}$ & $\begin{array}{c}0.542 \\
\pm 0.0059\end{array}$ & $\begin{array}{c}0.523 \\
\pm 0.017 \\
-3.55 \\
\mathrm{NS}\end{array}$ \\
\hline
\end{tabular}

Mean $\pm \mathrm{SD},+$ and - indicates percent increase and decrease , ' $\mathrm{p}$ ' denotes statistical significance and NS. Non-significant.

Table-3 Changes of ammonia in Aqua medium and tissues ( $\mu$ mol/gm body /lit $/ \mathrm{h}$ ) excretion by fry and fingerling on acclimation to acidic medium in comparison to control.

\begin{tabular}{|c|c|c|c|c|c|}
\hline \multirow{2}{*}{ S.No } & \multirow[t]{2}{*}{ Parameter } & \multicolumn{2}{|c|}{ Fry } & \multicolumn{2}{|c|}{ Fingerling } \\
\hline & & $\begin{array}{l}\text { Control } \\
\text { (pH 7.0) }\end{array}$ & $\begin{array}{c}\text { Sub lethal } \\
\text { (pH 5.5) }\end{array}$ & $\begin{array}{l}\text { Control } \\
\text { (pH 7.0) }\end{array}$ & $\begin{array}{c}\text { Sub lethal } \\
\text { (pH 5.5) }\end{array}$ \\
\hline 1. & $\begin{array}{c}\text { Aqua } \\
\text { Medium }\end{array}$ & $\begin{array}{c}2.14 \\
\pm 0.102\end{array}$ & $\begin{array}{c}1.36 \\
\pm 0.123 \\
-35.02 \\
\mathrm{P}<0.001\end{array}$ & $\begin{array}{c}2.23 \\
\pm 0.042\end{array}$ & $\begin{array}{c}1.27 \\
\pm 0.128 \\
-36.50 \\
\mathrm{P}<0.001\end{array}$ \\
\hline 2. & Tissue & $\begin{array}{c}13.45 \\
\pm 0.158\end{array}$ & $\begin{array}{c}6.36 \\
\pm 0.099 \\
-52.71 \\
\mathrm{P}<0.001\end{array}$ & $\begin{array}{c}25.31 \\
\pm 0.176\end{array}$ & $\begin{array}{c}6.481 \\
\pm 0.221 \\
-74.39 \\
\mathrm{P}<0.001\end{array}$ \\
\hline
\end{tabular}

Mean \pm SD, + and - indicates percent increase and decrease, 'p' denotes statistical significance and NS. Non-significant. 